\title{
Conto, logo existo
}

SANTOS, José (Org.). Todo mundo tem uma história para contar. São Paulo: Olhares: Museu da Pessoa, 2012. 176 p.

\author{
Francisco das Chagas Silva Souza \\ Instituto Federal do Rio Grande do Norte
}

O que há em comum entre um motorista, uma empregada doméstica, um repentista, uma professora, uma agricultora e um famoso jogador de futebol? $\bigcirc$ que distingue, mas também aproxima pessoas de profissões e classes sociais distintas? As suas histórias de vida.

A resposta pode ser trivial, mas não simplória. Isso é o que percebemos com base na leitura dos vinte relatos, selecionados entre os milhares disponíveis no Museu da Pessoa, publicados na obra Todo mundo tem uma história para contar, organizada pelo escritor José Santos, um dos sócios-fundadores desse museu.

O Museu da Pessoa está localizado em São Paulo e disponibiliza grande parte de seu acervo na internet. Criado em 1991, ele visa registrar, preservar e transformar, em informação, depoimentos sobre os trajetos de vida de qualquer pessoa da sociedade, sem distinções, que deseje salvaguardar as suas memórias, livrando-a do esquecimento. Essa postura valoriza a diversidade cultural e vê as experiências vividas pelos indivíduos como um patrimônio da humanidade e, por isso, dignas de ser guardadas como fonte de conhecimento e potencializadoras de vínculos em uma sociedade em que os laços de solidariedade estão, cada vez mais, frágeis.

Guiados por esse objetivo, os fundadores e organizadores do Museu da Pessoa conseguiram, ao longo de mais de duas décadas, reunir um amplo acervo. São 16 mil depoimentos em variados suportes, 25 mil horas de gravação em vídeos e cerca de 72 mil fotografias e documentos digitalizados. Além disso, o Museu da Pessoa já realizou 252 projetos, ganhou 19 prêmios e alcançou cerca de 50 mil professores e estudantes. Tendo sido o primeiro no mundo desse gênero, ele serviu de inspiração para a criação de mais três semelhantes no exterior, em Portugal, no Canadá e nos Estados Unidos. 
Produto desse acervo, a obra Todo mundo tem uma história para contar foi um dos finalistas do Prêmio Jabuti, em 2013, na categoria Biografia. Assim, em meio a personagens conhecidos da nossa história política, como D. Pedro I, José Bonifácio de Andrada e Silva, Getúlio Dornelles Vargas e Carlos Augusto Marighella, estavam 20 anônimos lexceção feita ao ex-jogador de futebol Raí) que resolveram narrar suas histórias de vida para os entrevistadores do Museu da Pessoa ou deixaram os seus relatos gravados no sítio. As narrativas são antecipadas por uma apresentação feita por nomes conhecidos da literatura, do jornalismo, da dramaturgia e de outras áreas.

A organização da obra não foi tarefa fácil, conforme afirmam, no prefácio, José Santos e Karen Worcman, sócios-fundadores e diretores do Museu. As histórias, envolventes e longas, precisaram ser recontadas por transcritores, editores e revisores, porém com o zelo para que fossem preservados o tom das falas, o ritmo de cada pessoa, as características do personagem. A nosso ver, apesar das dificuldades em realizar essa tarefa, ela teve um bom desfecho, haja vista a emoção que esses relatos causam ao visitarmos, por meio da leitura, vários "brasis", alguns reais e outros longe da nossa imaginação.

Em tempos e espaços diferenciados, as experiências vividas pelos 278 narradores descortinam um país rico de memórias, estas incrustadas nas tradições culturais, nos saberes e fazeres cotidianos, nas festas... São memórias que fazem emergir formas distintas de enxergar o mundo e atribuir significados às experiências vividas. Memórias que contribuem para ampliar os nossos horizontes e nos "descolar" de um mundo que nos é posto como se fosse o único real e possível. Em grande parte, são memórias expressas por intelectuais da tradição, aqueles "artistas de pensamento que, distantes dos bancos escolares e universidades, desenvolvem a arte de ouvir e ler a natureza à sua volta" (ALMEIDA, 2007, p. 10).

Antes de revelar tradições e perfis culturais das regiões do Brasil, as narrativas, apresentadas na obra Todo mundo tem uma história para contar, nos afetam, seduzem, enfeitiçam. Como não se comover, por exemplo, com a história da baiana Valdete Cordeiro? Pobre, órfã e adotada, Valdete desconhecia os sobrenomes dos seus pais e a data do seu nascimento. Mesmo assim, fez o seu aniversário em uma data célebre, 7 de setembro,e inventou um sobrenome: tornou-se uma Silva (2012, p. 67), como tantos outros de origens sociais semelhantes à dela. Sem dinheiro para comprar um bolo, "[...] arrumei uma caixinha de sapato, comprei as velas, [...] enfiei na caixa, foi meu bolo 
de aniversário", conta. Contudo, se isso produz, no leitor, um sentimento de compaixão, Valdete está longe da autopiedade e assegura que "foi uma festa maravilhosa".

Como essa, outras histórias também são carregadas de dramas e de traumas. Porém, seus personagens demonstram um alto potencial de resiliência e transformam as dores em histórias de sucesso. Tomemos,como exemplo,o relato de Roberto da Silva: criou-se na Febem, morou na rua, fez assaltos, foi presidiário, mas, mais tarde, estudou, tornou-se mestre em Sociologia e criou uma $\mathrm{ONG}$ cujo objetivo é promover a cidadania de pessoas que, igualmente a ele,foram vítimas de exclusão social.

O livro organizado por José Santos não, apenas, atesta o crescimento e o respeito que goza, hoje, a História Oral, mas também revela a adaptação desta aos novos suportes de guarda e divulgaçãode memórias. Como afirma Lévy (1999, p. 93), o ciberespaço põe em sinergia e interface todos os dispositivos de criação de informação, gravação, comunicação e simulação. Dessa forma, esse autor previa, há quase duas décadas: "[...] a perspectiva da digitalização geral das informações provavelmente tornará o ciberespaço o principal canal de comunicação e suporte de memória da humanidade a partir do início do próximo século".

A era digital alargou o acesso às fontes para os pesquisadores. Ela nos permitiu produzir e usar áudios e vídeos, acessar on line registros orais e escritas, publicar no ambiente virtual, guardar e compartilhar registros da memória. Assim, ela reduziu práticas intimistas, como a escrita de diários geralmente guardados a sete chaves. Em uma época quandotudo é fluido e "se desmancha no ar", é necessário dar-se a existir e se ver existente. Narrar as experiências vividas, deixá-las a salvo do esquecimento, certamente, dá ao sujeito a sensação de solidez, resistência, força diante das incertezas do devir. Mesmo que seu relato anuncie fatos que, para o narrador, seja da ordem do fracasso e da necrose, essa narrativa poderá se constituir num instrumento pelo qual o sujeito protagonista traçará uma outra trajetória que the proporcionará um novo fluxo de vida.

Portanto, recorrer à Web como uma forma de quebrar o silêncio e o anonimato parece ser a melhor saída para os que acessam o Museu da Pessoa e ali postam as suas histórias. Da mesma maneira o é para os que preferem dirigir-se ao seu espaço físico e narrar, em uma cabine, suas experiências de 
vida. Seja qual for a maneira escolhida, ali, diante de uma câmera,é possível "abrir-se", afetar e enfeitiçar o outro.

Prof. Dr. Francisco das Chagas Silva Souza Instituto Federal do Rio Grande do Norte Professor do Programa de Pós-Graduação em Educação Profissional E-mail | chagas.souza@ifrn.edu.brr

Recebido 9 set. 2015 Aceito 13 jun. 2016 